\title{
Effect of Industrial Dust Deposition on Photovoltaic Module Performance: Experimental Measurements in the Tropical Region
}

\author{
Yotham Andrea $\mathbb{D}^{1}{ }^{1}$ Tatiana Pogrebnaya, ${ }^{1}$ and Baraka Kichonge $\mathbb{D}^{2}$ \\ ${ }^{1}$ Department of Materials and Energy Science and Engineering (MESE), Nelson Mandela African Institution of Science and \\ Technology (NM-AIST), P.O. Box 447, Arusha, Tanzania \\ ${ }^{2}$ Department of Mechanical Engineering, Arusha Technical College (ATC), P.O. Box 296, Arusha, Tanzania
}

Correspondence should be addressed to Yotham Andrea; andreay@nm-aist.ac.tz

Received 16 September 2019; Revised 21 November 2019; Accepted 4 December 2019; Published 20 December 2019

Guest Editor: Jorge Esteban Rodas Benítez

Copyright $\odot 2019$ Yotham Andrea et al. This is an open access article distributed under the Creative Commons Attribution License, which permits unrestricted use, distribution, and reproduction in any medium, provided the original work is properly cited.

Dust particle accumulation affects outdoor photovoltaic module transmittance of solar cell glazing and thus leads to significant degradation of conversion efficiency owing to lower irradiance reaching the surface. In this study, the sensitivity of the polycrystalline silicon photovoltaic module towards industrial dust deposition was experimentally investigated under the tropical climatic condition of Arusha, Tanzania. Dust involved in the study came from fertilizer, gypsum, aggregate crusher, and coal mine industries. The experimental measurements were outdoor conducted under $720 \mathrm{~W} / \mathrm{m}^{2}, 800 \mathrm{~W} / \mathrm{m}^{2}$, and $900 \mathrm{~W} / \mathrm{m}^{2}$ solar irradiances. Results indicated that dust accumulation on the polycrystalline silicon photovoltaic module negatively affected output power as well as short-circuit current, however having no significant impact on open-circuit voltage. Maximum module efficiency loss was observed to be $64 \%, 42 \%, 30 \%$, and $29 \%$ for coal, aggregate, gypsum, and organic fertilizer dust, respectively; hence, coal dust was the most effecting dust among the four. It was also demonstrated that PV module performance deteriorated with temperature rise owing to heat dissipation caused by dust accumulation.

\section{Introduction}

Global climate change, energy security, and potential exhaustion of fossil fuel reserves have attracted renewable energy technology development [1, 2]. Approximately $80 \%$ of energy consumption in the world is from fossil fuels which significantly contributed to climate change [3]. Application of renewable energy technology is valuable due to less impact on environmental degradation as well as the unlimited resource availability [4]. Away from being sustainable, solar energy symbolizes the most favorable renewable energy resources [5]. Solar energy harvesting through the use of photovoltaic (PV) systems for the production of electricity is well thought out as one of the potential markets in the field of renewable energy [6,7]. Electricity production through the conversion of solar radiation into electricity materializes as a result of photovoltaic effect [8-10]. Energy conversion through the use of PV technologies does not cause serious environmental challenges as compared to conventional power generation sources, such as fossil fuels [11]. The pres- ent conversion efficiency of PV systems is approximated at different efficiencies ranging between 7 and $40 \%[12,13]$.

PV system operations encompass features such as module technology, battery type, and converter topology. Despite these features, the PV system is exposed to environmental agents such as aging, radiation, shading, temperature variations, wind, and dust accumulation [14-16]. Climate change contributes to sunlight availability variation causing rises in air temperature, which may always affect performance efficiency of the PV module. Solar tracking technology has emerged to assist PV systems in capturing maximum solar irradiance thus an increase of power output [17]. Dust is among the factors that affect the performance efficiency of PV module worldwide output [18-20]. The smallest particle size of less than $500 \mu \mathrm{m}$ is termed as dust $[21,22]$. The morphological structure, composition, and deposition of dust always depend on location characteristics [23]. Reduction in PV module performance highly depends on particle size and surface density of dust deposited over the modules [24]. Deposition of dust on a panel influences the solar cell 


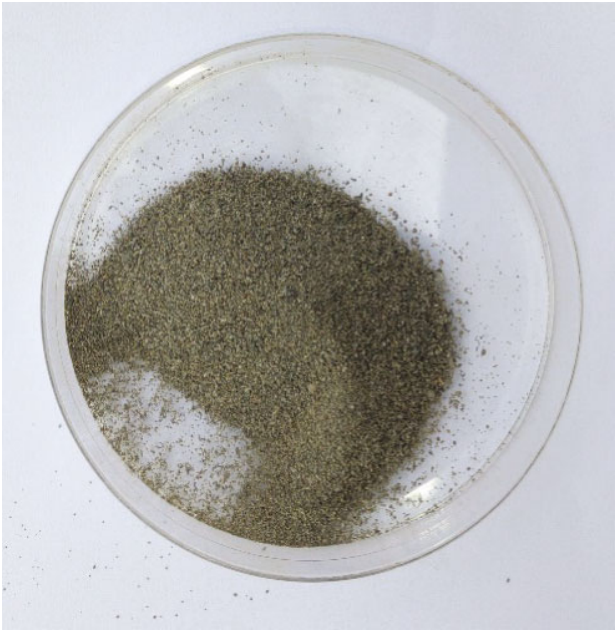

(a)

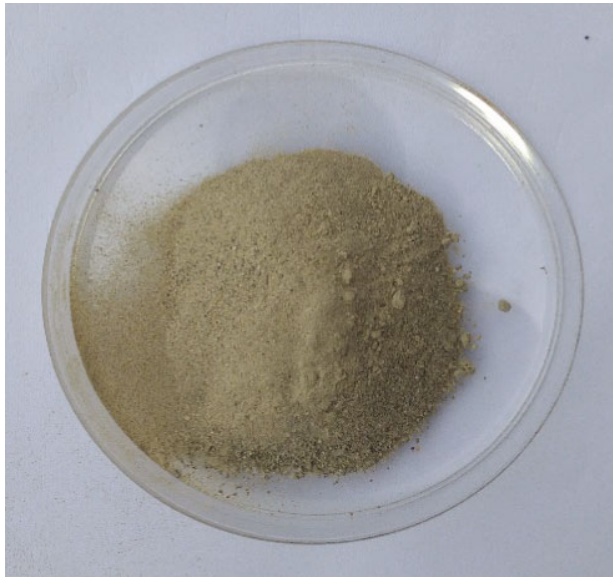

(c)

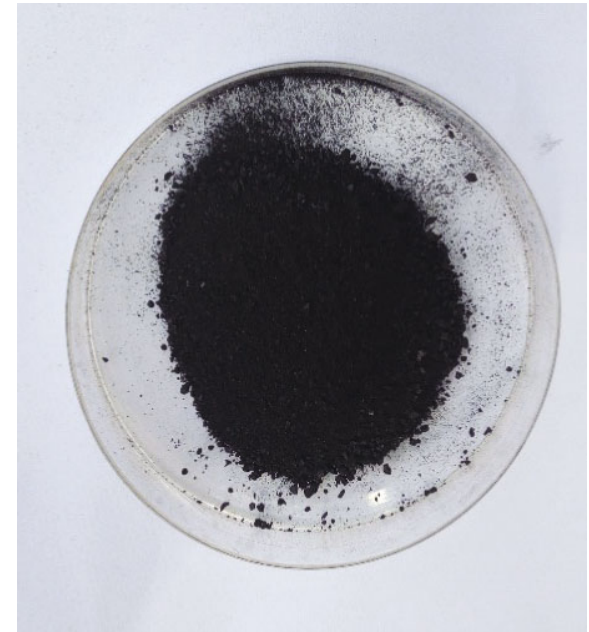

(b)

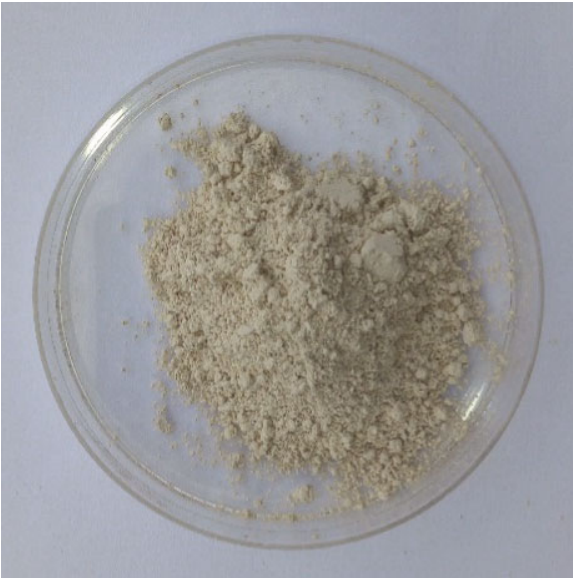

(d)

FIGURE 1: Dust samples used for the experimental study: (a) aggregate crusher dust; (b) coal dust; (c) fertilizer industry dust; (d) gypsum industry dust.

to heat up whereby affected cells will act as a resistance to the generated current; this tendency may lead to substantial degradation of conversion efficiency and even to formation of a hot spot that can ultimately damage the PV module $[25,26]$. Due to minimal interparticle distance between fine particles, a small amount of solar radiation can pass through; therefore, it reduces more performance efficiency of a module compared with the larger particles $[27,28]$.

There are existing studies on the effect of dust on solar $\mathrm{PV}$ performance, but much of the information available is only valid for a specific location [29, 30]. Generally, there is a lack of relevant information on the effects of soil dust deposition for a specific location in Tanzania that can be effectively utilized in the design and sizing of PV modules. Deposition of dust on the PV panel blocks solar radiation from reaching cells. Density, composition, and particle size distribution of accumulated soil dust have been shown to have a significant impact on power generated by hindering solar radiation from reaching the cells through the glass cover of the panel [23]. Unawareness of the soil dust effect might bring to improper maintenance of solar PV systems and loss of some energy.
TABLe 1: PV module technical characteristics.

\begin{tabular}{lc}
\hline Electrical specification & Value \\
\hline Maximum power & $100 \mathrm{~W}$ \\
Current at maximum power $\left(I_{\mathrm{mp}}\right)$ & $5.36 \mathrm{~A}$ \\
Voltage at maximum power $\left(V_{\mathrm{mp}}\right)$ & $18.65 \mathrm{~V}$ \\
Short-circuit current $\left(I_{\mathrm{sc}}\right)$ & $5.71 \mathrm{~A}$ \\
Open-circuit voltage $\left(V_{\mathrm{oc}}\right)$ & $22.25 \mathrm{~V}$ \\
Nominal operating cell & $45 \pm 2^{\circ} \mathrm{C}$ \\
temperature $\left(T_{\text {noct }}\right)$ & $1020 \mathrm{~mm} * 675 \mathrm{~mm} * 25 \mathrm{~mm}$ \\
Module dimension &
\end{tabular}

This study is aimed at experimentally investigating the performance degradation of PV module output power caused by a different type of industrial dust deposition. In achieving its objectives, the study estimated the impact of dust from manufacturing and mining industries. The study provides information, which may help users in better maintenance of the system and gain more power output. 


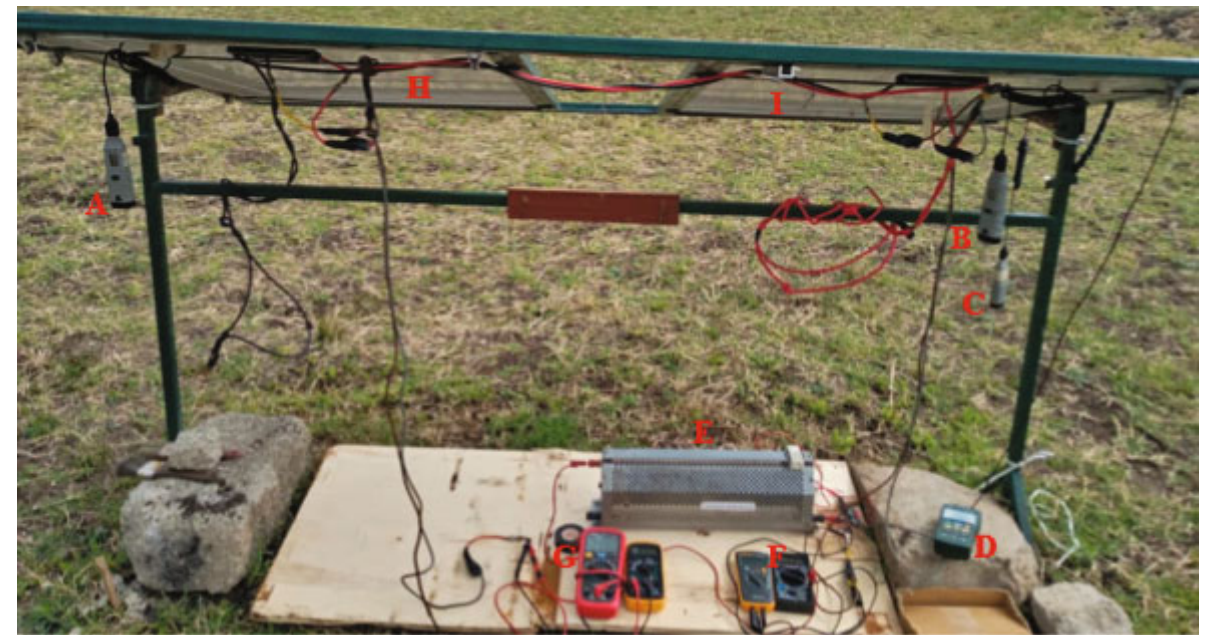

FIGURE 2: Equipment and accessories: (a-c) data loggers with temperature and humidity sensors; (d) solar meter; (e) rheostat; (f, g) digital multimeters; $(h, i)$ solar panels.

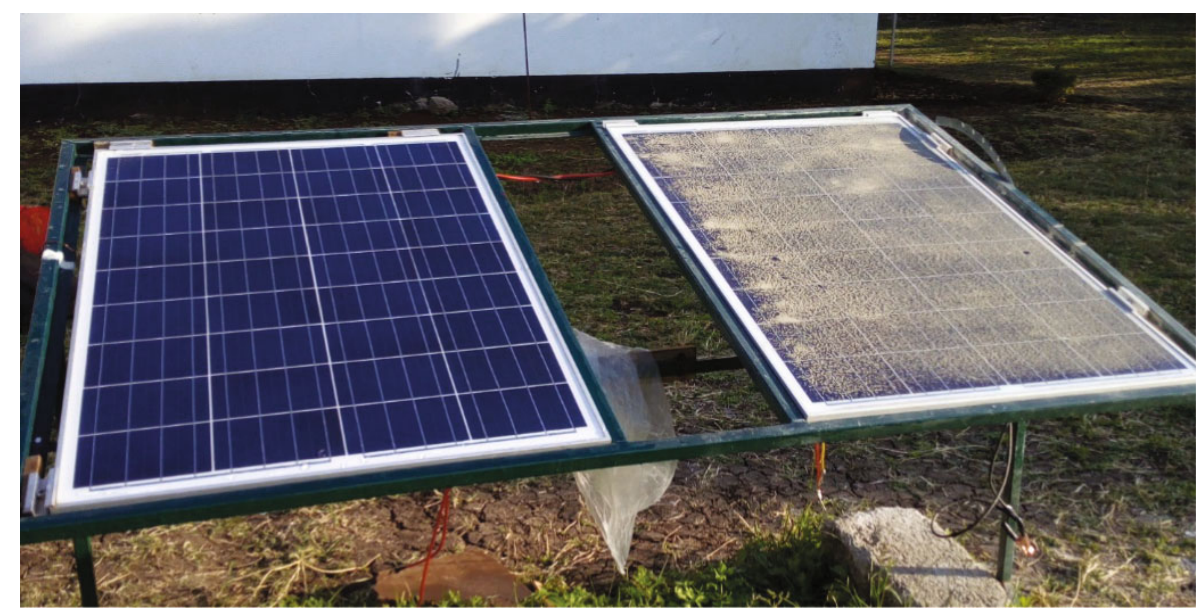

Figure 3: PV module experimental setup.

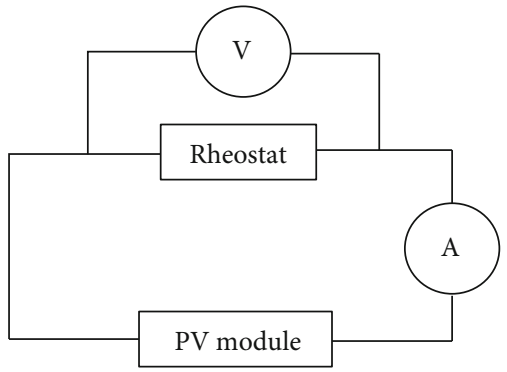

FIgURE 4: PV module circuit diagram for $I-V$ curve measurements.

\section{Materials and Methods}

2.1. Materials Used in This Study. Dust samples were collected from manufacturing and mining industries located in different parts of Tanzania. The four dust samples (Figure 1) were selected from Organic Fertilizer Industry (Minjingu), Saint Gobain Lodhia Gypsum Industry, Mining Aggregate Crusher located in Arusha City, and Ngaka Coal Mining located in Ruvuma-southern part of Tanzania.
2.2. Dust Sample Preparation. Particle size analysis for the collected samples was conducted at NM-AIST Laboratories. The collected samples were sieved into different particle size ranges $90 \mu \mathrm{m}-180 \mu \mathrm{m}, 45 \mu \mathrm{m}-90 \mu \mathrm{m}$, and $20 \mu \mathrm{m}-45 \mu \mathrm{m}$ under sieve analysis technique. The system comprised of stowage of the sieves with dissimilar sieve holes, and the smallest sieve was placed at the bottommost of the stack. The technique separates particles from a bigger size to the smallest size according to the sieve arrangement. Each sample was weighted by digital weight before putting it on the upper sieve set; then, the sieve set was placed on the Retsch sieve shaker, vibration frequency was configured, and the Retsch sieve shaker was allowed to start and stop after 15 minutes. After the Retsch sieve shaking completed, each sieve was taken to the digital weight balance and weighted.

2.3. Experimental Setup. The experiment was conducted in an outdoor environment at the Innovative Technology and Energy Centre within the Nelson Mandela African Institution of Science and Technology premises, Tanzania (latitude $-3.23^{\circ} \mathrm{S}$, longitude $36.47^{\circ} \mathrm{E}$ ). Two identical photovoltaic 

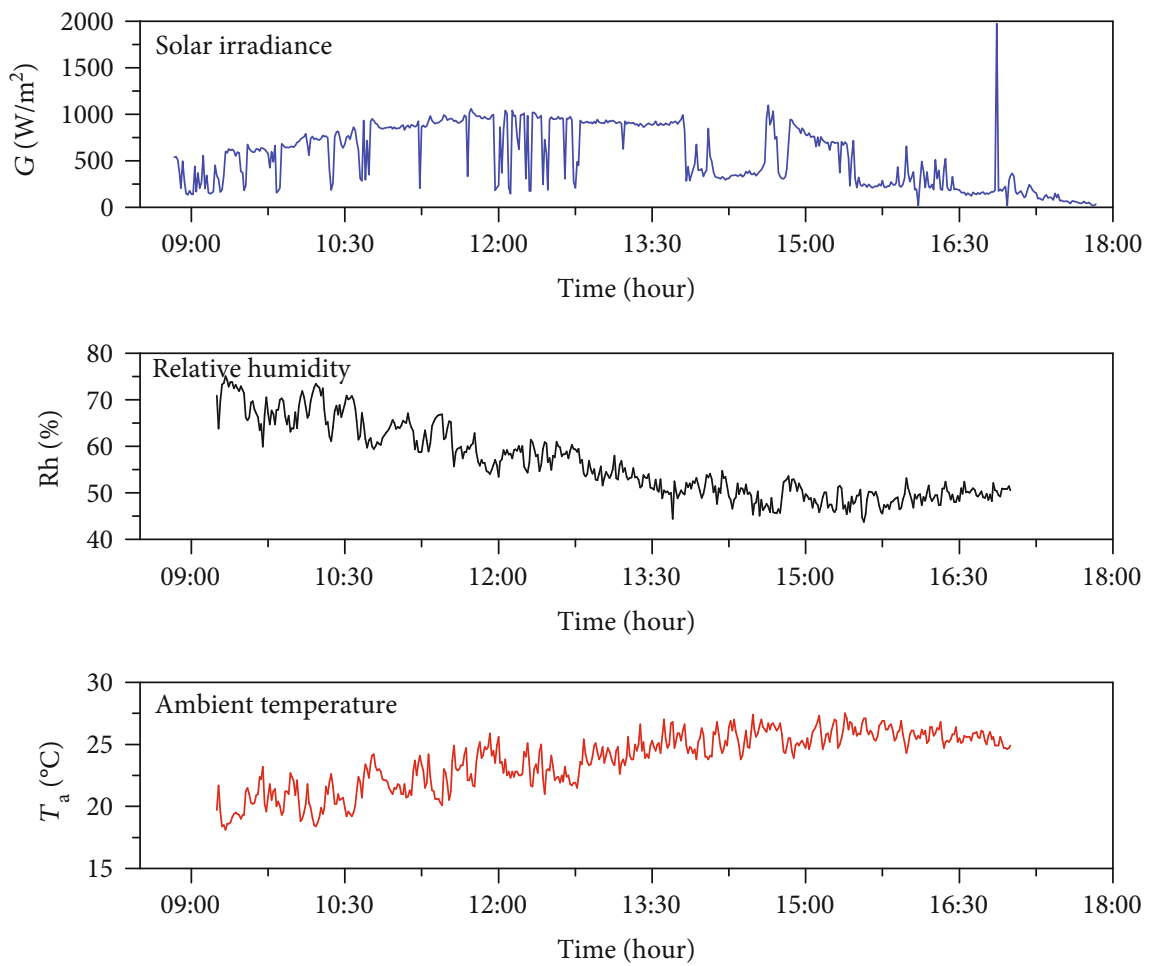

FIGURE 5: Weather parameter data taken at the site.

TABLE 2: Temperature effect on a clean module performance.

\begin{tabular}{lcccccccc}
\hline & $G=720 \mathrm{~W} / \mathrm{m}^{2}$ & & \multicolumn{3}{c}{$G=800 \mathrm{~W} / \mathrm{m}^{2}$} & \multicolumn{3}{c}{$G=900 \mathrm{~W} / \mathrm{m}^{2}$} \\
$T_{p}\left({ }^{\circ} \mathrm{C}\right)$ & $P_{\max }(\mathrm{W})$ & $\eta(\%)$ & $T_{p}\left({ }^{\circ} \mathrm{C}\right)$ & $P_{\max }(\mathrm{W})$ & $\eta(\%)$ & $T_{p}\left({ }^{\circ} \mathrm{C}\right)$ & $P_{\max }(\mathrm{W})$ & $\eta(\%)$ \\
\hline 30.0 & 83.8 & 16.9 & 37.3 & 86.0 & 15.6 & 30.6 & 96.7 \\
31.0 & 67.0 & 13.5 & 42.1 & 81.0 & 14.7 & 32.6 & 86.2 \\
31.5 & 65.0 & 13.1 & 48.3 & 79.4 & 14.4 & 39.9 & 84.3 & 13.9 \\
42.1 & 63.0 & 12.7 & 48.5 & 75.0 & 13.6 & 40.3 & 79.4 \\
46.4 & 62.5 & 12.6 & 48.6 & 65.0 & 11.8 & 41.6 & 78.8 \\
\hline
\end{tabular}

modules of the model SLP100-12 manufactured by Kishen Enterprises Ltd. (Jiangsu, China) with rated maximum power of $100 \mathrm{~W}$ and 45 cell (each of $105 \mathrm{~mm}$ width and $155 \mathrm{~mm}$ length) polycrystalline silicon were tilted at $15^{\circ}$ angle facing north; electrical characteristics of the panels are shown in Table 1. The experiment is aimed at assessing the effects of dust deposition over the PV module; four different types of dust collected from different sites were tested to assess impact on the PV module performance. One module was covered with dust while another module was left clean for output power comparison purposes. The cleaning method of the dirty module may be with a fine brush [31], which was also adopted for this study in cleaning the polluted panel.

Accessories and equipment used for experimental measurements are presented in Figure 2 where $\mathrm{H}$ and I are solar PV modules. The USB SSN-11e data loggers represented by $A$ and $B$ were attached at the back of the module surface for monitoring module operating temperature. The USB SSN-22e data logger C was attached to the panel

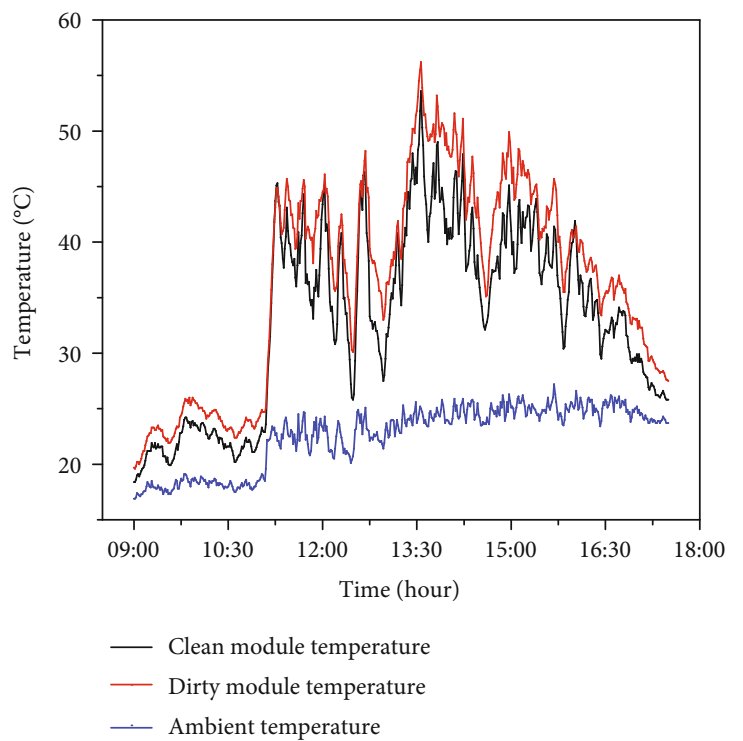

Figure 6: Ambient air and PV module operating temperature. 


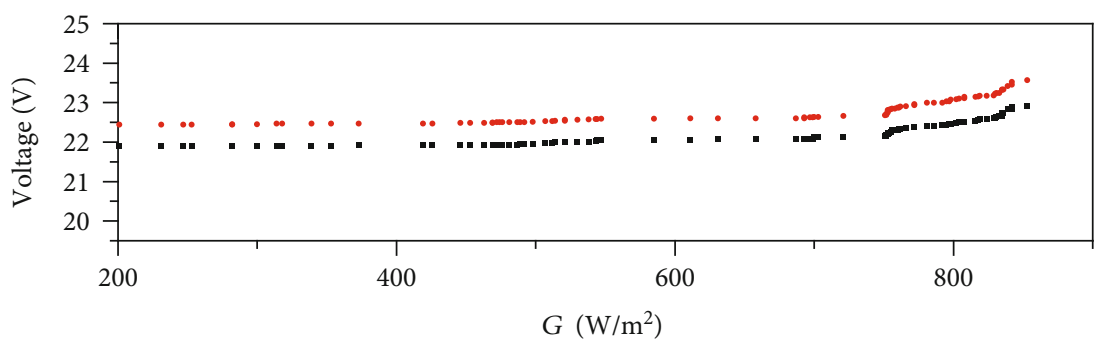

$$
\begin{aligned}
& \text {... Clean module } \\
& \text {... Dirty module }
\end{aligned}
$$

(a)

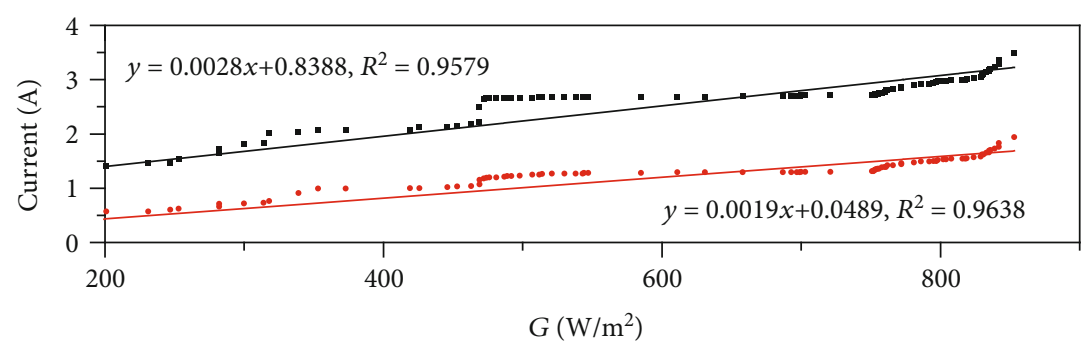

— Current for clean module

— Current for dirty module

(b)

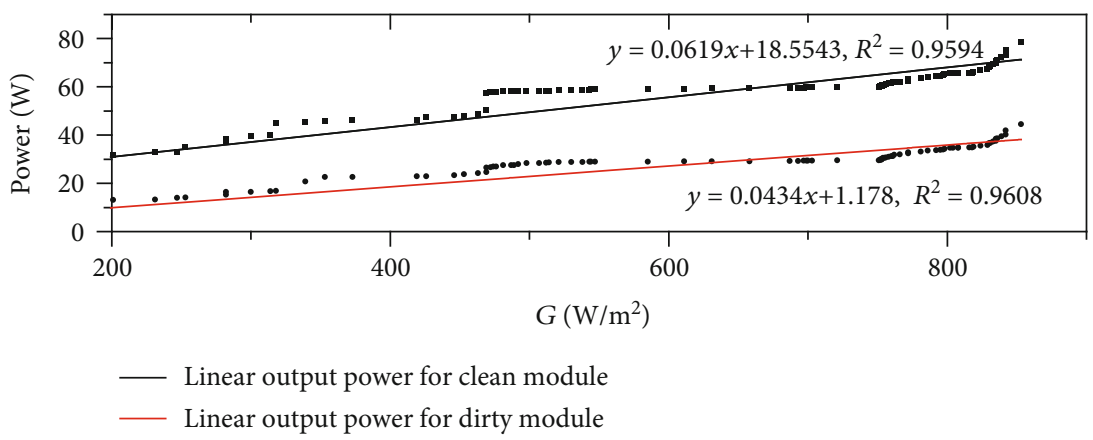

(c)

FIGURE 7: Impact of solar irradiance on operating voltage, current, and power output for clean and dirty modules (45-90 $\mu \mathrm{m}$ aggregate dust).

frame while its sensor was left hanging for recording air temperature and relative humidity. The solar meter TES 132 USB indicated by letter D, with its sensor attached to the module surface (with the same inclination angle as the PV module), was employed for monitoring solar irradiation intensity reaching the module. Furthermore, rheostat E (load variable resistor) and digital multimeters $\mathrm{G}$ and $\mathrm{F}$ were used for current and voltage monitoring. Each module was connected to digital voltmeter and ammeter; current and voltage were measured by supplying power to a rheostat, as depicted in Figure 3 and circuit diagram in Figure 4; current-voltage $(I-V)$ and powervoltage $(P-V)$ correlations were examined.

The measurements were performed at clear sky condition during the day; performance degradation assessment for the PV module was done at three different solar irradiances $720 \mathrm{~W} / \mathrm{m}^{2}, 800 \mathrm{~W} / \mathrm{m}^{2}$, and $900 \mathrm{~W} / \mathrm{m}^{2}$. Weight of $10 \mathrm{~g}$ for each dust sample was weighted by the digital weight balance. Dust was uniformly distributed over the module with a baby powder bottle covered with sieve mesh in front of it (Figure 3).

2.4. Data Processing and Measurements. The experiment was done under three different selected solar irradiances for all four dust samples under particle size range. Instantaneous current and voltage were recorded at real-time condition. The efficiency of the module depends on several factors including design and maintenance of the panel, temperature, and solar irradiance $(G)$, and it may be calculated through the following equations:

$$
\begin{gathered}
P_{\text {max }}=I_{\mathrm{mp}} \times V_{\mathrm{mp}}, \\
\eta=\frac{P_{\max }}{G \times A},
\end{gathered}
$$

where $A$ is the surface area of the panel. From the individual module efficiency, performance efficiency loss $\eta_{\text {loss }}$ of the PV 

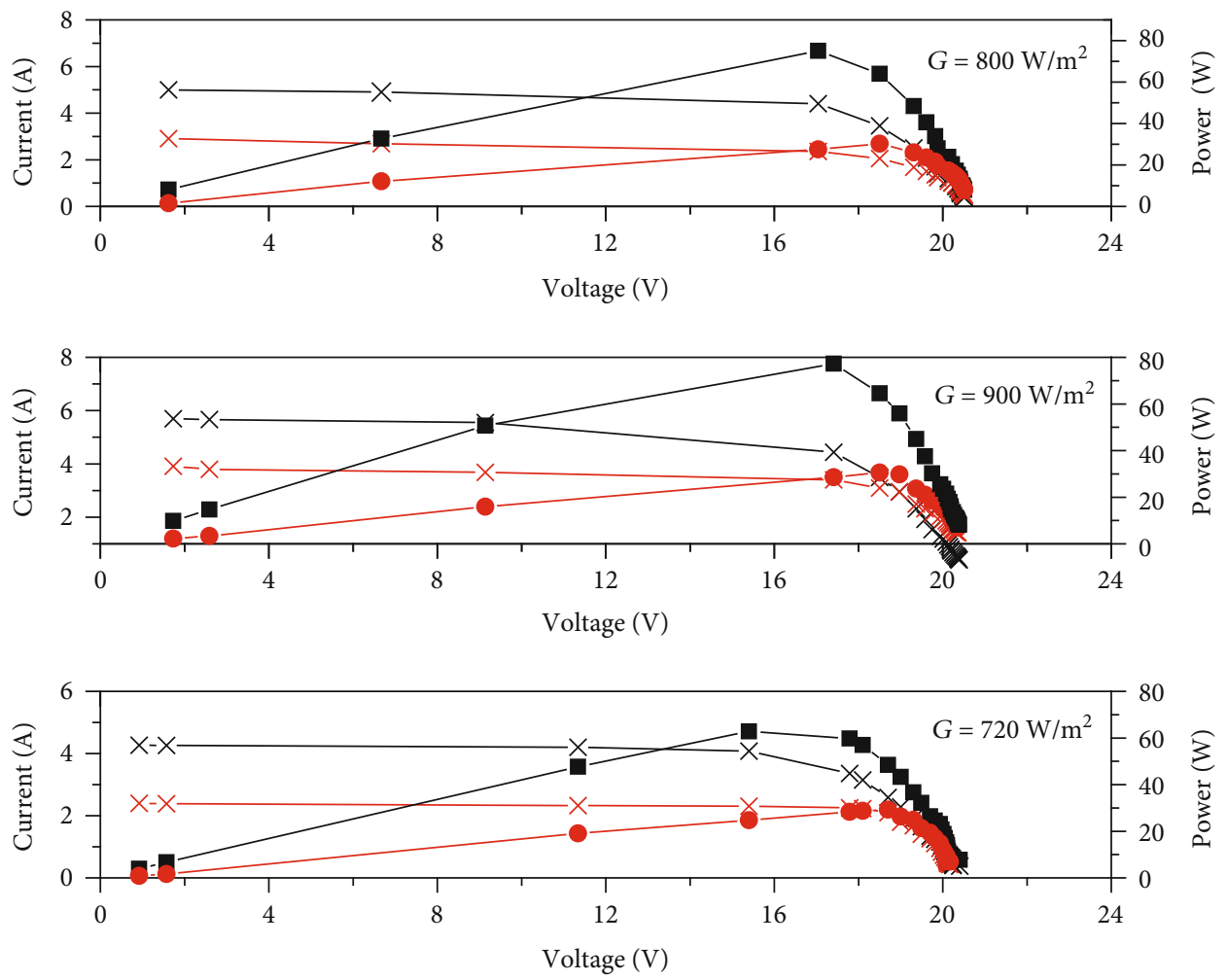

Figure 8: $I-V$ and $P-V$ curves are represented in thin and bolded lines, respectively, while black and red colours represent clean and dirty modules, respectively (with $20-45 \mu \mathrm{m}$ coal dust).

module can be calculated through Equation (3), by using the relationship [32]:

$$
\eta_{\text {loss }}=\frac{\eta_{\text {clean }}-\eta_{\text {dirty }}}{\eta_{\text {clean }}} \times 100
$$

\section{Results and Discussion}

This section presents data acquired from experimental measurement and analysis. The first part is about a variation of weather condition during experimental measurements in the study area. PV module performance, power, and current output drop due to dust deposition; PV module efficiency is shown in the second section. In the last part, analysis of results is given regarding the impact of temperature and different types and particle sizes of dust on the PV module performance.

3.1. Variation of Weather Condition at the Site. As described in Figure 5, during data collection in the study area, there was fluctuation of weather condition, i.e., solar radiation, relative humidity, and ambient temperature. It was observed that solar radiation was high from 12:00 AM to 03:00 PM; also, ambient temperature was increasing from morning towards 03:00 PM. Moreover, relative humidity was high during the morning time and was decreasing towards noontime; this indicated that as sunlight intensity increased, relative humidity decreased. Short-term varia- tions of weather parameters are normally caused by turbulences within the atmosphere.

3.2. PV Power and Efficiency Loss due to Temperature for a Clean Panel. In this study, power and efficiency losses due to temperature on the PV module were investigated; the assessment was done for the clean module. Change in power $P_{\max }$ and efficiency yield due to temperature effect at different solar irradiances $\left(720 \mathrm{~W} / \mathrm{m}^{2}, 800 \mathrm{~W} / \mathrm{m}^{2}\right.$, and $\left.900 \mathrm{~W} / \mathrm{m}^{2}\right)$ were assessed (Table 2). Experimental results proved that temperature rise reduced $P_{\max }$ and module efficiency as well. Minimum and maximum module temperatures were observed to be $30.0^{\circ} \mathrm{C}$ and $48.6^{\circ} \mathrm{C}$, respectively, whereby $P_{\max }$ rose to $97 \%$ of rated power and dropped to the minimum level of $63 \%$ accordingly. At $G=900 \mathrm{~W} / \mathrm{m}^{2}$ and $T=$ $30.6^{\circ} \mathrm{C}$, the $P_{\max }=96.7 \mathrm{~W}$ was very close to the rated value, and efficiency was also high, $\eta=15.6 \%$. In average, the power decreased by $1.3-1.8 \mathrm{~W}$ and efficiency lowered by $\sim 0.3 \%$, per each degree in temperature rise.

3.3. Impact of Dust on PV Module Temperature. Dust accumulation on the PV module has also impact on the cell operating temperatures. The observation was made during the experimental test when aggregate dust with particle size 20-45 $\mu \mathrm{m}$ was deposited over the module, whereby temperature difference between the clean and dirty modules was observed to be varying between $1{ }^{\circ} \mathrm{C}$ and $9^{\circ} \mathrm{C}$ (Figure 6). The abrupt rise of cell operating temperature for both modules (at 11:10 AM) occurred which may be caused by the sudden 
TABle 3: $P_{\max }, I_{\mathrm{sc}}$, and $V_{\mathrm{oc}}$ for clean and dirty modules under fine particles.

\begin{tabular}{|c|c|c|c|c|c|c|c|c|c|c|}
\hline \multirow{2}{*}{$G\left(\mathrm{~W} / \mathrm{m}^{2}\right)$} & \multicolumn{4}{|c|}{ Clean module } & \multicolumn{4}{|c|}{ Dirty module } & \multirow{2}{*}{$\begin{array}{l}P_{\max }(\text { dirty }) / P_{\max } \\
(\text { clean })(\%)\end{array}$} & \multirow{2}{*}{$\begin{array}{l}I_{\mathrm{sc}}(\text { dirty }) / I_{\mathrm{sc}} \\
(\text { clean })(\%)\end{array}$} \\
\hline & $P_{\max }(\mathrm{W})$ & $V_{\mathrm{oc}}(\mathrm{V})$ & $I_{\mathrm{sc}}(\mathrm{A})$ & $T_{p}\left({ }^{\circ} \mathrm{C}\right)$ & $P_{\max }(\mathrm{W})$ & $V_{\mathrm{oc}}(\mathrm{V})$ & $I_{\mathrm{sc}}(\mathrm{A})$ & $T_{p}\left({ }^{\circ} \mathrm{C}\right)$ & & \\
\hline \multicolumn{11}{|c|}{ Fertilizer industry dust } \\
\hline 720 & 65.2 & 21.1 & 2.6 & 31.5 & 48.3 & 20.8 & 1.9 & 33.1 & 74.1 & 74.5 \\
\hline 800 & 41.1 & 20.6 & 4.1 & 32.6 & 29.1 & 20.3 & 3.2 & 37.0 & 70.8 & 76.5 \\
\hline 900 & 84.2 & 20.5 & 5.7 & 43.0 & 65.8 & 20.3 & 4.6 & 49.0 & 78.1 & 80.4 \\
\hline \multicolumn{11}{|c|}{ Aggregate dust } \\
\hline 720 & 25.4 & 20.2 & 1.7 & 29.6 & 16.6 & 19.7 & 1.2 & 32.2 & 65.4 & 72.1 \\
\hline 800 & 41.1 & 20.6 & 2.6 & 31.8 & 23.8 & 20.0 & 1.7 & 36.4 & 57.9 & 63.1 \\
\hline 900 & 85.9 & 20.3 & 5.7 & 49.9 & 49.9 & 19.6 & 3.7 & 47.8 & 58.1 & 64.0 \\
\hline \multicolumn{11}{|l|}{ Coal dust } \\
\hline 720 & 62.8 & 20.4 & 4.3 & 42.1 & 29.3 & 20 & 2 & 49.9 & 46.6 & 46.8 \\
\hline 800 & 75.2 & 20.5 & 5.0 & 48.6 & 26.9 & 20.1 & 2.2 & 48.7 & 35.8 & 43.6 \\
\hline 900 & 77.3 & 20.4 & 5.7 & 35.6 & 27.6 & 19.9 & 2.5 & 39.5 & 35.7 & 43.9 \\
\hline \multicolumn{11}{|c|}{ Gypsum industry dust } \\
\hline 720 & 84.2 & 20.7 & 4.5 & 30.8 & 62.3 & 20.5 & 3.7 & 32.3 & 74.0 & 81.1 \\
\hline 800 & 65.0 & 20.2 & 5.0 & 48.3 & 45.8 & 19.8 & 4.1 & 51.3 & 70.5 & 82.1 \\
\hline 900 & 96.7 & 20.5 & 6.3 & 49.3 & 72.9 & 20.2 & 4.8 & 50.3 & 75.4 & 75.8 \\
\hline
\end{tabular}

rise of solar irradiance. Moreover, increase or decrease in cell operating temperature also depends on the solar irradiance intensity reaching the panel surface. Our observation about impact of dust on the PV panel temperature is agreed with the study done by [33], which reported that dirty module temperature was observed to be higher compared with the clean one. Due to dust accumulation, the incoming solar irradiation over the panel tends to be hindered. Deposited dust also leads to heat dissipation to the dirty module [34]. This is the reason why the temperature of the dirty module is higher compared to the clean one.

3.4. Impact of Dust on Solar PV Performance. A mass of $10 \mathrm{~g}$ from aggregate dust with a particle size of $45-90 \mu \mathrm{m}$ was distributed uniformly over the module before the measurement. The data were acquired on operating electrical parameters, voltage, current, and power output, from both clean and dirty modules simultaneously. There was difference in voltage $\sim 0.5 \mathrm{~V}$ between clean and dirty modules, where dirty module voltage was observed to be higher (Figure 7). It was examined that the current and power outputs were linearly increasing with solar irradiation intensity as shown in Figures 7 (b) and 7 (c). However, the current drop due to dust deposition was ranging between $1.0 \mathrm{~A}$ and $1.5 \mathrm{~A}$, and output power drop was $20 \mathrm{~W}-40 \mathrm{~W}$.

Furthermore, the experimental measurement for $I-V$ and $P$ - $V$ curves for the all tested samples at different irradiances was conducted, but in this paper, $I-V$ and $P-V$ curves for the fine particles $(20-45 \mu \mathrm{m})$ from coal dust were selected to represent (Figure 8) because fine particles from coal dust have been observed to affect most the module performance compared with the other samples. For $720 \mathrm{~W} / \mathrm{m}^{2}$, $800 \mathrm{~W} / \mathrm{m}^{2}$, and $900 \mathrm{~W} / \mathrm{m}^{2}$ irradiances, the output current $\left(I_{\mathrm{sc}}\right)$ reduction due to dust deposition was $53 \%, 56 \%$, and $32 \%$, respectively.

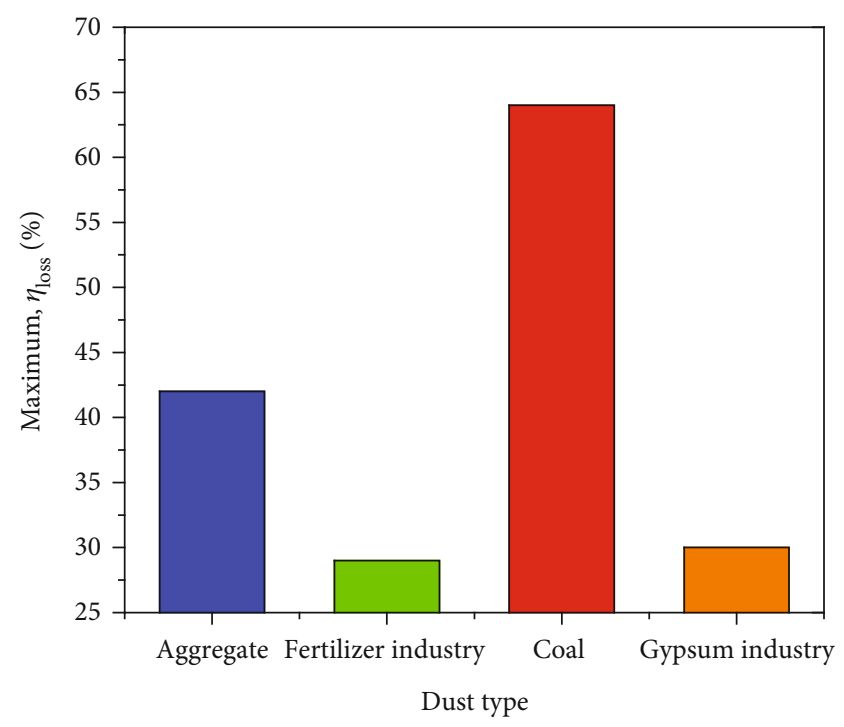

FIGURE 9: Maximum efficiency loss basing on dust with particle size 20-45 $\mu \mathrm{m}$.

\subsection{Analysis of Results}

3.5.1. $P_{\max }, I_{s c}$, and $V_{o c}$ Loss due to Dust Deposition. The impact of dust deposition with fine particles $(20-45 \mu \mathrm{m})$ on power $P_{\max }$ and current $I_{\mathrm{sc}}$ is shown in Table 3 for all four dust types. It has been examined that dust accumulation does not have a substantial impact on open-circuit voltage of the PV module; this observation is correlated with the study conducted by [31]. Open-circuit voltage of the dirty module is lower than that of the clean module to some extent for all solar irradiances. Dust deposition has a significant impact on short-circuit current generated by the modules. The clean module reliably generates higher output current; the ratio $I_{\mathrm{sc}}$ (dirty) $/ I_{\text {sc }}$ (clean) ranges from $43 \%$ to $82 \%$ for all tested dust 

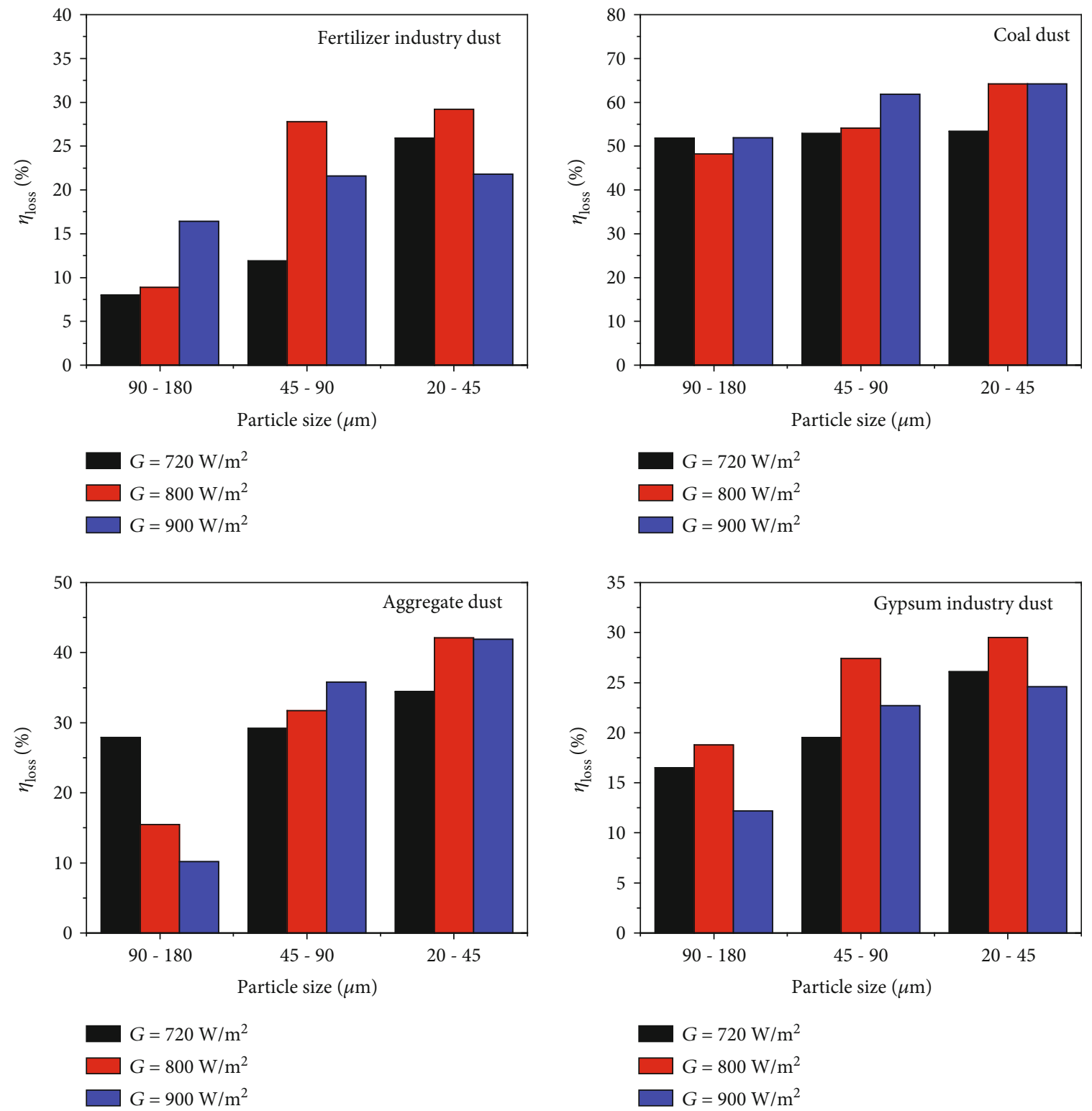

Figure 10: Performance efficiency loss for the four tested dust samples.

types under all solar irradiances as depicted at the last column in Table 3. The disparity in output current reduction may be caused by the fluctuations in solar irradiance received by the module at real-time condition. More strong effect of dust is seen on maximum power. The ratio of $P_{\max }$ (dirty) $/ P_{\max }$ (clean) varies from $36 \%$ to $78 \%$ for different types of dust. $P_{\max }$ produced by the coal dusted panel is reduced most drastically, more than twice (by 53\%-64\%), compared to the clean one. Less impact on power is resulted from fertilizer and gypsum dusts where the drop in $P_{\max }$ occurred by $22-30 \%$. Therefore, dust accumulation on the photovoltaic module negatively affected output power as well as short-circuit current, however, had no significant impact to open-circuit voltage.

3.5.2. Effect of Dust Type and Particle Size. Dust collected from different sources has shown to have a dissimilar impact on performance efficiency reduction of the PV module. It was observed that performance losses depend on the dust type (Figure 9). The coal dust was observed to have a higher impact on efficiency loss among the four types of dust. This fact is quite apprehensible owing to the highest absorptivity of the coal sample. Close to one absorptivity and hence lowest transmissivity of the coal dust are brought about by less sun energy reaching the panel as well as by additional heating of it as compared to other types of dust.

Moreover, the study done by [35] reported that module efficiency losses were progressively increased with the decrease in particle size. In the current study, the fine particles were also observed to bring higher performance efficiency losses in the PV performance as depicted in Figure 10. Therefore, the results agreed with the earlier authors [28] who reported that fine particles inhibit solar irradiance from passing through them due to the minimal 
interparticle gap in between them. Therefore, with the observation stated also by [35], it is the reason for the fine particles to have a significant impact in efficiency loss compared with larger particles. The maximum performance efficiency loss was examined to be $64 \%$ for coal dust at a particle size of $20 \mu \mathrm{m}-45 \mu \mathrm{m}$ (fine particle), while $48 \%$ was the minimum efficiency loss occurring at $90 \mu \mathrm{m}-180 \mu \mathrm{m}$ (large particle) at irradiance of $800 \mathrm{~W} / \mathrm{m}^{2}$. In addition, for the same solar irradiance and the same particle sizes, dust from the fertilizer industry revealed to have $29 \%$ maximum and $9 \%$ minimum efficiency loss. However, for aggregate dust tested at $900 \mathrm{~W} / \mathrm{m}^{2}, 42 \%$ was the maximum efficiency loss occurring at $20 \mu \mathrm{m}-45 \mu \mathrm{m}$ (fine particle size) while $10 \%$ was observed to be the minimum performance loss for $90 \mu \mathrm{m}-180 \mu \mathrm{m}$ (larger particle size). These are experimental justifications observed in this study; fine particles have more significant impact on performance efficiency loss on the PV module as compared to course particles.

\section{Conclusion}

Performance efficiency loss of the polycrystalline silicon module due to industrial dust deposition was investigated. Dust samples were collected from fertilizer, gypsum, aggregate crusher, and coal mine industries. The outdoor experimental measurement of the polycrystalline module performance was done; impact of dust deposition was determined by attaining operating parameters as well as the $I-V$ and $P-V$ characteristic curves of similar modules exposed to the same operating environment (i.e., solar irradiance and air temperature) while one module was covered with dust and the other was reserved clean for output comparison. It was examined that the efficiency loss depended on the type of dust accumulated over the panel surface. Maximum efficiency loss of the polycrystalline photovoltaic module was observed to be $64 \%, 42 \%, 30 \%$, and $29 \%$ for coal, aggregate, gypsum, and organic fertilizer dust, respectively; hence, coal dust was the most effecting dust sample among the four owing to its highest absorptivity and hence lowest transmissivity. Also, the study proved that the finer dust particles reduced more performance efficiency compared with the larger particles. It was also found that the PV module performance deteriorated with temperature rise owing to heat dissipation caused by dust accumulation. The ratio of short-circuit currents for the dirty module to the clean module was in the range of $43-82 \%$ for all dust types tested under different sunlight intensities. Drop in current output due to dust deposition leads to power output drop which causes an immense loss of electrical power and, consequently, economic loss to photovoltaic power in consideration of the large-scale solar power plant.

\section{Abbreviations}

PV: Photovoltaic

$G$ : $\quad$ Solar irradiance

$I-V: \quad$ Current-voltage curve

$P-V:$ Power-voltage curve

$I_{\mathrm{mp}}$ : Current at maximum power
$V_{\mathrm{mp}}$ : Voltage at maximum power

$I_{\text {sc }}: \quad$ Short-circuit current

$V_{\text {oc }}$ : Open-circuit voltage

$T_{\text {noct }}$ : Nominal operating cell temperature

$P_{\text {max }}$ : Maximum power

$\eta: \quad$ Efficiency

$\eta_{\text {clean }}:$ Clean module efficiency

$\eta_{\text {dirty }}$ : Dirty module efficiency

Rh: Relative humidity

$T_{\mathrm{a}}$ : Ambient temperature.

\section{Data Availability}

The data used to support the findings of this study are available from the corresponding author upon request.

\section{Conflicts of Interest}

The authors would like to declare that they have no conflicts of interest that might have influenced the performance or presentation of the work described in this paper.

\section{Acknowledgments}

The authors of this paper would like to give their great thanks to Water Infrastructure and Sustainable Energy Future for financing all processes regarding the preparation of this article. Great thanks should go to my fellow students from the Nelson Mandela African Institution of Science and Technology for their encouragement in the preparation of this work. Also, many thanks should go to Dr. Rhee Herb from Innovative Technology and Energy for providing electrical measurement accessories. Moreover, I would like to thank Eng. Kaare Manyama from Greenlink Energy for his support on the provision of some equipment and accessories for the experimental setup. The findings reported in this article were financed by Water Infrastructure and Sustainable Energy Future (Project ID: PI51847).

\section{References}

[1] S. Kirmani, M. Jamil, and I. Akhtar, "Economic feasibility of hybrid energy generation with reduced carbon emission," IET Renewable Power Generation, vol. 12, no. 8, pp. 934-942, 2018.

[2] K. Bos and J. Gupta, "Climate change: the risks of stranded fossil fuel assets and resources to the developing world," Third World Quarterly, vol. 39, no. 3, pp. 436-453, 2018.

[3] B. Joseph, T. Pogrebnaya, and B. Kichonge, "Semitransparent building-integrated photovoltaic: review on energy performance, challenges, and future potential," International Journal of Photoenergy, vol. 2019, Article ID 5214150, 17 pages, 2019.

[4] J. P. N. Torres, S. K. Nashih, C. A. F. Fernandes, and J. C. Leite, "The effect of shading on photovoltaic solar panels," Energy Systems, vol. 9, no. 1, pp. 195-208, 2018.

[5] A. Bonkaney, S. Madougou, and R. Adamou, "Impacts of cloud cover and dust on the performance of photovoltaic module in Niamey," Journal of Renewable Energy, vol. 2017, Article ID 9107502, 8 pages, 2017. 
[6] J. Khan and M. H. Arsalan, "Solar power technologies for sustainable electricity generation - a review," Renewable and Sustainable Energy Reviews, vol. 55, pp. 414-425, 2016.

[7] F. Obeidat, "A comprehensive review of future photovoltaic systems," Solar Energy, vol. 163, pp. 545-551, 2018.

[8] P. Singh and S. Gupta, "Photovoltaic surface in plug-in electric vehicle (Pev) using nanotechnology," Journal of Scientific and Technical Advancements, vol. 5, no. 1, pp. 33-38, 2019.

[9] P. Rappaport, "The photovoltaic effect and its utilization," Solar Energy, vol. 3, no. 4, pp. 8-18, 1959.

[10] L. K. John Perlin and S. Moon, "Silicon solar cell 50," in 3rd World Conference on PV Energy Conversion, pp. 23-24, Osaka, Japan, 2004.

[11] B. Su, W. Han, Y. Chen, Z. Wang, W. Qu, and H. Jin, "Performance optimization of a solar assisted CCHP based on biogas reforming," Energy Conversion and Management, vol. 171, pp. 604-617, 2018.

[12] M. Debbarma, K. Sudhakar, and P. Baredar, "Comparison of BIPV and BIPVT: a review," Resource-Efficient Technologies, vol. 3, no. 3, pp. 263-271, 2017.

[13] M. A. Green, Y. Hishikawa, E. D. Dunlop, D. H. Levi, J. Hohl-Ebinger, and A. W. Y. Ho-Baillie, "Solar cell efficiency tables (version 52)," Progress in Photovoltaics: Research and Applications, vol. 26, no. 7, pp. 427-436, 2018.

[14] E. Adıgüzel, E. Özer, A. Akgündoğdu, and A. Ersoy Yılmaz, "Prediction of dust particle size effect on efficiency of photovoltaic modules with ANFIS: an experimental study in Aegean region, Turkey," Solar Energy, vol. 177, pp. 690-702, 2019.

[15] R. S. Anjos, R. Melício, V. M. Mendes, and H. M. Pousinho, "Crystalline silicon PV module under effect of shading simulation of the hot-spot condition," in Doctoral Conference on Computing, Electrical and Industrial Systems, L. CamarinhaMatos, M. Parreira-Rocha, and J. Ramezani, Eds., pp. 479487, Springer, Cham, 2017.

[16] Z. A. Darwish, H. A. Kazem, K. Sopian, M. A. Alghoul, and H. Alawadhi, "Experimental investigation of dust pollutants and the impact of environmental parameters on PV performance: an experimental study," Environment, Development and Sustainability, vol. 20, no. 1, pp. 155-174, 2018.

[17] A. E. Hammoumi, S. Motahhir, A. E. Ghzizal, A. Chalh, and A. Derouich, "A simple and low-cost active dual-axis solar tracker," Energy Science \& Engineering, vol. 6, no. 5, pp. 607620, 2018.

[18] K. Vidyanandan, An Overview of Factors Affecting the Performance of Solar PV Systems, vol. 27, Energy Scan House J Corp Plan NTPC Ltd, New Delhi, 2017.

[19] B. R. Paudyal and S. R. Shakya, "Dust accumulation effects on efficiency of solar PV modules for off grid purpose: a case study of Kathmandu," Solar Energy, vol. 135, pp. 103-110, 2016.

[20] D. S. Rajput and K. Sudhakar, "Effect of dust on the performance of solar PV panel," International Journal of Chem Tech Research, vol. 5, no. 2, pp. 1083-1086, 2013.

[21] J. Tanesab, D. Parlevliet, J. Whale, and T. Urmee, "The effect of dust with different morphologies on the performance degradation of photovoltaic modules," Sustainable Energy Technologies and Assessments, vol. 31, pp. 347-354, 2019.

[22] A. Pan, H. Lu, and L.-Z. Zhang, "Experimental investigation of dust deposition reduction on solar cell covering glass by different self-cleaning coatings," Energy, vol. 181, pp. 645-653, 2019.
[23] B. Aïssa, R. J. Isaifan, V. E. Madhavan, and A. A. Abdallah, "Structural and physical properties of the dust particles in Qatar and their influence on the PV panel performance," Scientific Reports, vol. 6, no. 1, pp. 1-12, 2016.

[24] K. Styszko, M. Jaszczur, J. Teneta et al., "An analysis of the dust deposition on solar photovoltaic modules," Environmental Science and Pollution Research, vol. 26, no. 9, pp. 8393-8401, 2019.

[25] A. K. Tripathi, M. Aruna, and C. S. N. Murthy, "Performance of a PV panel under different shading strengths," International Journal of Ambient Energy, vol. 40, no. 3, pp. 248-253, 2017.

[26] W. He, F. Liu, J. Ji, S. Zhang, and H. Chen, "Safety analysis of solar module under partial shading," International Journal of Photoenergy, vol. 2015, Article ID 907282, 8 pages, 2015.

[27] H. Lu and W. Zhao, "Effects of particle sizes and tilt angles on dust deposition characteristics of a ground-mounted solar photovoltaic system," Applied Energy, vol. 220, pp. 514-526, 2018.

[28] A. A. Hachicha, I. Al-Sawafta, and Z. Said, "Impact of dust on the performance of solar photovoltaic (PV) systems under United Arab Emirates weather conditions," Renewable Energy, vol. 141, pp. 287-297, 2019.

[29] S. A. Sulaiman, H. H. Hussain, N. Leh, and M. S. Razali, "Effects of dust on the performance of PV panels," World Academy of Science, Engineering and Technology, vol. 58, no. 2011, pp. 588-593, 2011.

[30] M. T. Chaichan and H. A. Kazem, "Effect of sand, ash and soil on photovoltaic performance: an experimental study," International Journal of Scientific Engineering and Science, vol. 1, no. 2, pp. 27-32, 2017.

[31] M. Mostefaoui, A. Ziane, A. Bouraiou, and S. Khelifi, "Effect of sand dust accumulation on photovoltaic performance in the Saharan environment: southern Algeria (Adrar)," Environmental Science and Pollution Research, vol. 26, no. 1, pp. 259-268, 2019.

[32] H. Ali, M. Zafar, M. Bashir, M. Nasir, M. Ali, and A. Siddiqui, "Effect of dust deposition on the performance of photovoltaic modules in Taxila, Pakistan," Thermal Science, vol. 21, no. 2, pp. 915-923, 2017.

[33] A. Rao, R. Pillai, M. Mani, and P. Ramamurthy, "Influence of dust deposition on photovoltaic panel performance," Energy Procedia, vol. 54, pp. 690-700, 2014.

[34] S. Liu, Q. Yue, K. Zhou, and K. Sun, "Effects of particle concentration, deposition and accumulation on photovoltaic device surface," Energy Procedia, vol. 158, pp. 553-558, 2019.

[35] W. Javed, Y. Wubulikasimu, B. Figgis, and B. Guo, "Characterization of dust accumulated on photovoltaic panels in Doha, Qatar," Solar Energy, vol. 142, pp. 123-135, 2017. 

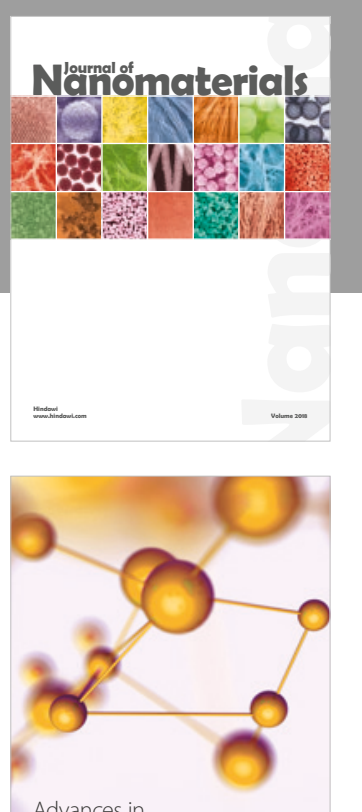

Physical Chemistry
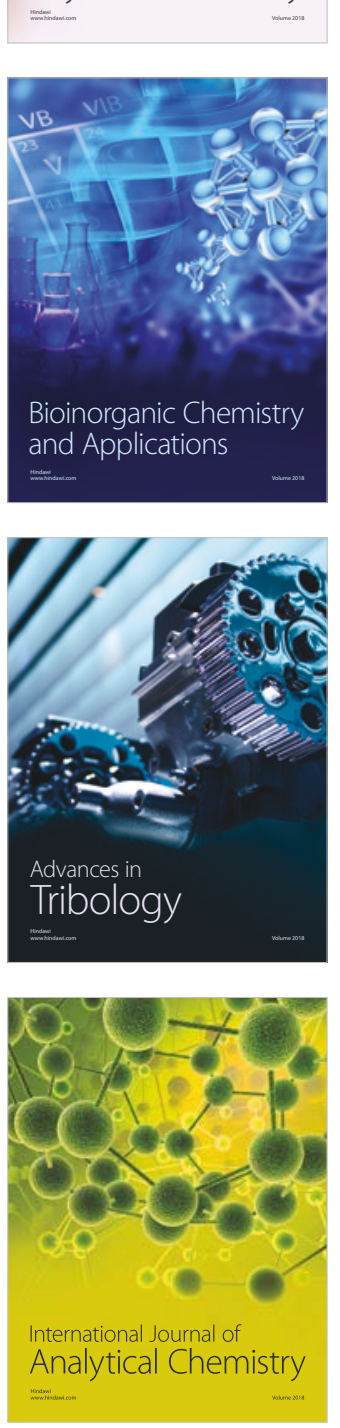

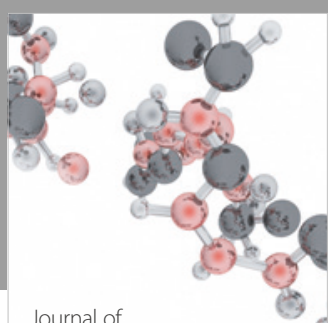

Analytical Methods

in Chemistry

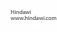

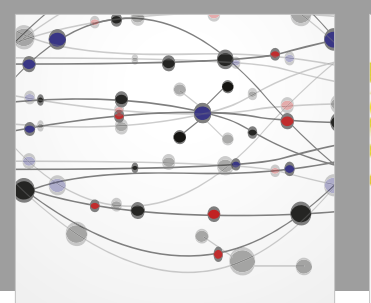

The Scientific World Journal

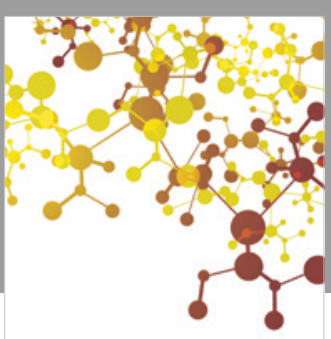

Journal of

Applied Chemistry
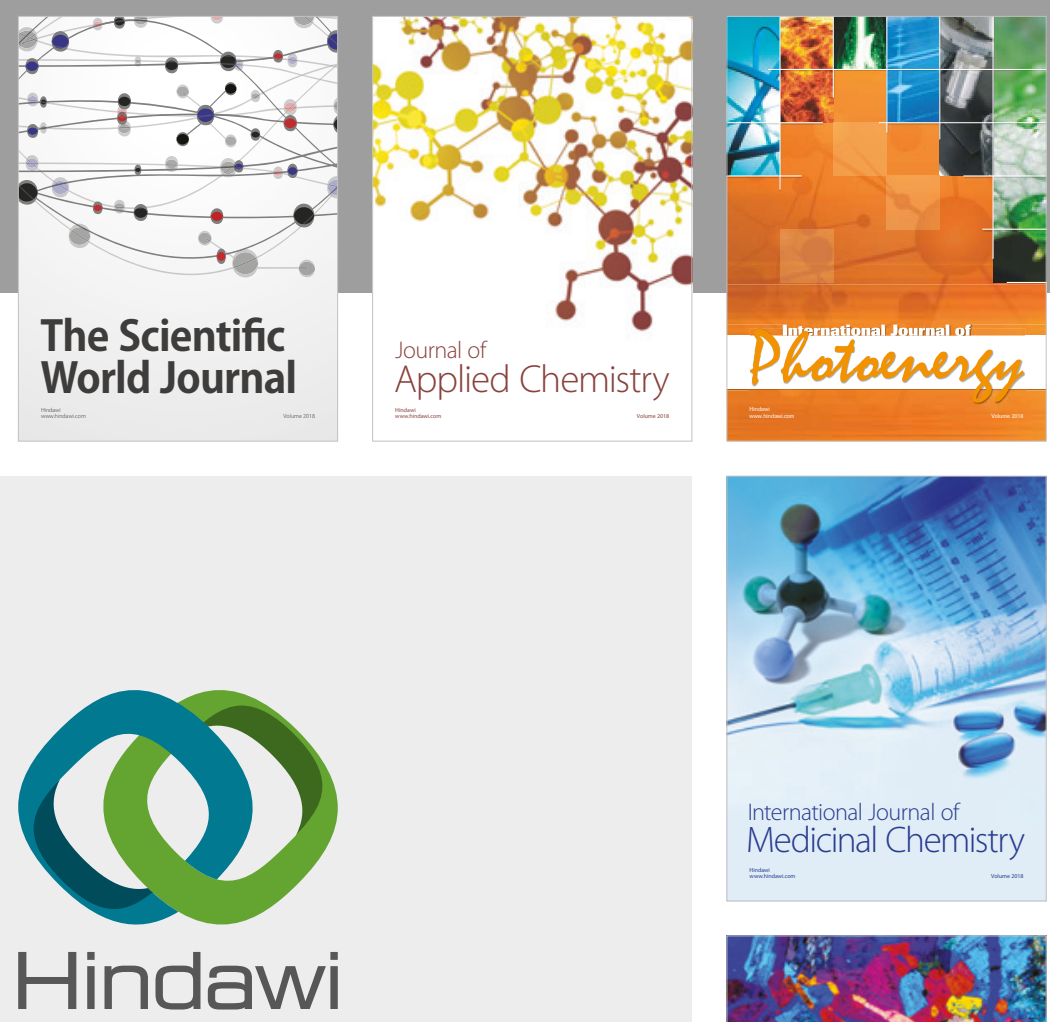

Submit your manuscripts at

www.hindawi.com
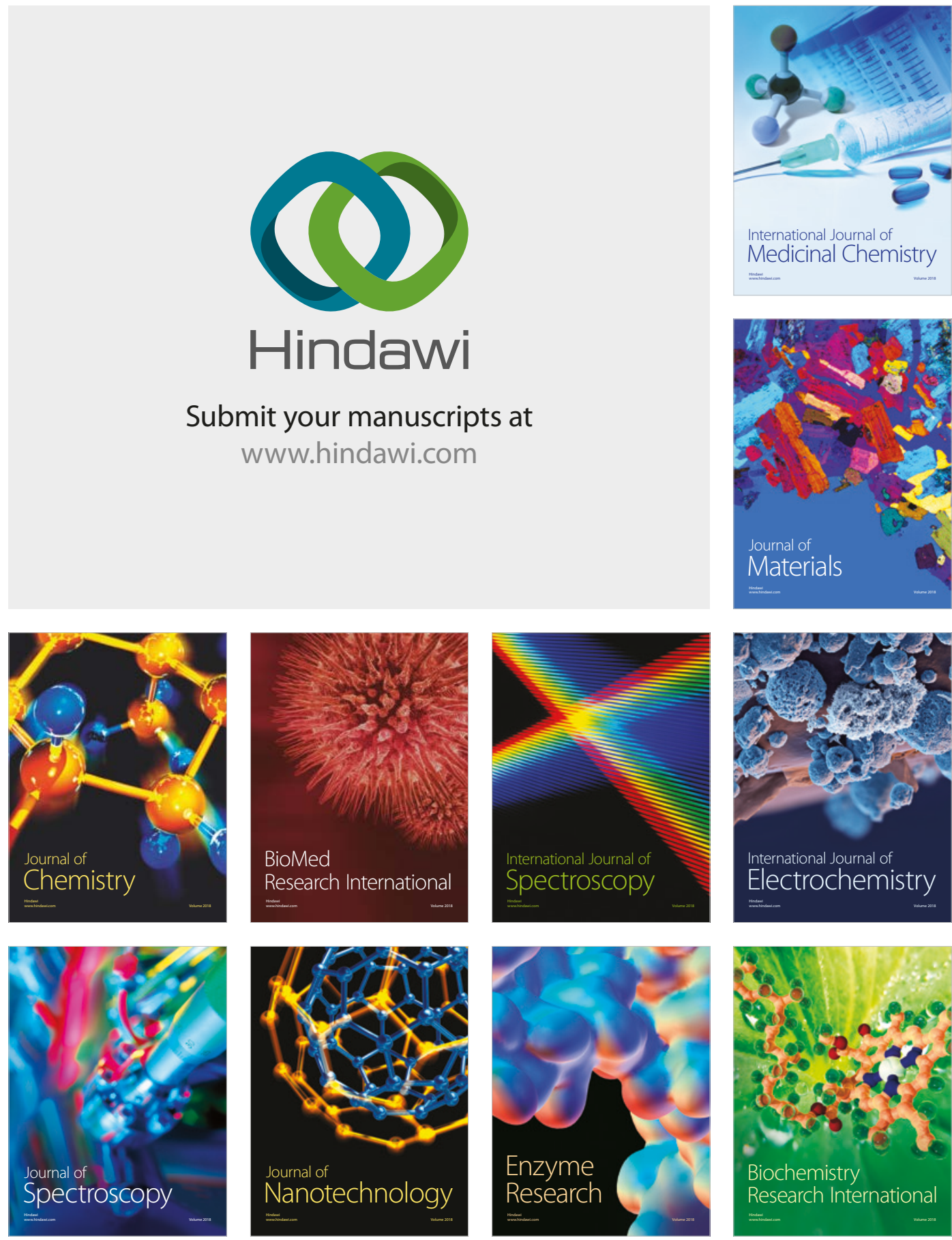
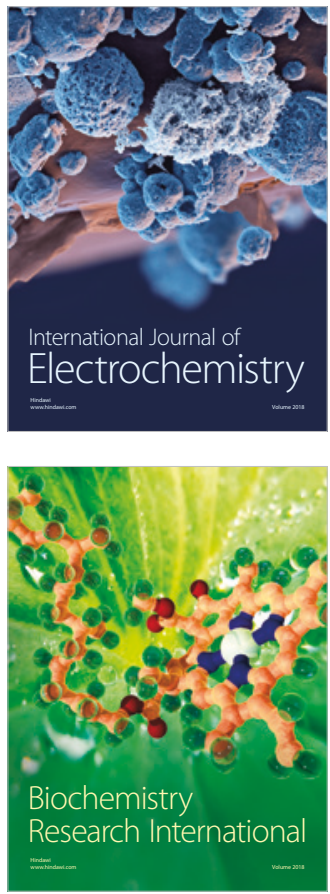